\title{
Broadcasting Management: The Strategy of Television Production Configuring for Sustainability in the Digital Era
}

\author{
Rizki Briandana ${ }^{1}$, Mohammad Irfan ${ }^{2}$
}

\author{
${ }^{1}$ Faculty of Communication, Universitas Mercu Buana, Jakarta-Indonesia \\ ${ }^{2}$ Faculty of Economics and Business, Universitas Mercu Buana, Jakarta-Indonesia
}

\begin{abstract}
This research will focus on media management strategy in television broadcasting stations as a way of defending sustainability in the digital age. The production team has an important role in the success of a program. Ithas responsibility pre-production, production and post-production activities. It is not an easy thing for the production team to maintain the aired programs with high demand and rating. The theory used in this research is the Theory of Broadcast Media Management Strategy covering four broadcast management functions, i.e. planning, organizing, actuating, and controlling.

This research used the descriptive qualitative approach. The research selected case study method with observation and interview data collection techniques. Based on the research results it is found that as improving the program rating, the internal team makes several innovations, such as the increase of hosts, the uses of gimmick, the change of studio settings, the keeping of interactive quizzes, the utilization of social media and the establishment of good communication processes in the team. Moreover, the research results also show that the applied innovation has a positive impact on the increase of rating and share, and so for television broadcasting stations it is a strategy to keep competitive in the digital world.
\end{abstract}

Keywords - strategy, management, broadcasting, Indonesian television broadcasting.

\section{INTRODUCTION}

In the digital era, the profit of conventional television stations has decreased dramatically(Hisamatsu, Mitsuhashi, Saito, \& Sakao, 2008). Audience shifts their interest to digital television stations. Therefore, the conventional television stations have to survive and get business challenge in the middle of the digital era (Eilein Landers \& Chan-Olmsted, 2004).

In an effort to survive, conventional broadcasting stations "writhed"(Oberg, 2000). They also take advantagesto this information technology development by media convergence(Jung \& Walden, 2015). In this context media convergence refers to television stations that are starting to transform digital systems(Malmelin \& Moisander, 2014).

Television is the fastest-growing media in technology and so, it is relatively expensive media (particularly for television broadcasting stations)(Bennett \& Strange, 2011). Television has various entertainment packages in such a way so that it attracts and entertains the audience. Fiske (2012) states that the functions of mass communication consists of surveillance (supervision), interpretation, linkage (interconnection), value transmition (distribution of values) and entertainment. According to
Baran \& Davis (2011), the functions of mass communication have to: convince (persuasion), confer status, anesthetize (narcotization), create a sense of unity, privatization, and parasocial relationships.

In this context, many television stations in Indonesia have complaints due to change to digital direction(Sudibyo \& Patria, 2013). In this matter, Metro TV has changed its creative concepts and management strategies in order that it it stays afloat in the digital age.

The success of a television program can be measured on the viewership's (Bennett \& Strange, 2011). There is a formula in the broadcasting sector that a good program will get greater audience. On the contrary, a bad program will not get listeners or audience(Aji, Wibisono, \& Gunawan, 2017). Therefore, a program can be rated as good if the program can meet the audiences' tastes and they want to follow the presented programs. A great number of the audiences can be measured on the program ratings(Greer \& Ferguson, 2011).

Rating is average number of television program viewers compared to television population in percentages and measured on various scales with certain indicators(Danaher, 1995). Itis important because advertisers are always looking for the most watched 
broadcast stations or programs. Television stations need ratings as income(Linder \& Gentile, 2009).As the main income, advertisers judge television stations and whatprograms include the most watched ones. With the ratings, the advertisers can manage their operation costs more efficiently(Danaher, 1995). Finally, their ads will reach the target and so, there are as many as possible consumers watch their ads.

Therefore, this research aims at analyzing the implementation of a television program's management strategy to maintain its business in the digital age.

\section{LITERATURE REVIEW}

\section{Broadcasting Media Management}

A broadcast program is a program containing a series of messages(Lawson-Borders, 2006). The messages become sounds and images. The sounds and images themselves form graphics and characters whether they are interactive or not and the broadcast televisions will broadcast them(Küng-Shankleman, 2012). The broadcast programs are all kinds that broadcast stations present to meet the audiences' needs. For the broadcast programs that many audiences like, production activities have to apply well management. For the well management, the content creators should know the existing phases in the broadcasting media management(Lawson-Borders, 2006).

According to Mcguire, Stoner, \& Mylona (2008), management is the process of planning, organizing, directing, and supervising the efforts of the members of the organization and the use of other organizational resources in order to achieve the stated organizational goals.

Moreover, other opinion states that management is a series of activities in which there is a different process, i.e. planning, organizing, actuating, and controlling and therefore, it can use the existing resources to achieve goals in effective and efficient way(Terry, 1992).

Therefore, it can be concluded that production management in broadcasting station operations is the process of program preparation that a broadcasting station will broadcast through several phases, i.e. planning, organizing, directing, and controlling all matters in relation to the production process.

Terry (1992)divides four basic functions of management, i.e. planning, organizing, actuating and controlling. These four management functions are called POAC.

\section{Planning}

Planning is the most important phase in organizations. The process decide what goals and ways the organizations will achieve. It is a series of activities related to the efforts to formulate a program which contains everything to be carried out, determine objectives and policies, direction to be taken as well as procedures and methods to be followed in the efforts to achieve the goals. Planning carried out in broadcast media management, i.e. during the pre-production process includes the determination of the ideas or content ideas that will be produced, the sources and the production budget.

2. Organizing

Organizing is a process in which the organizations organize and distribute works among members of the organization and therefore, the organizational goals can be achieved efficiently. The organizing function in the broadcast media management can be realized during the division of tasks in the production process. In the process of television production, each member has his/her own duties and responsibilities, such as producer, production assistant, creative team, event director, cameraman, lightingman, audioman, makeup and wardrobe, and editor.

3. Actuating

Actuating is the implementation phase in achieving the organizational goals. In the broadcast media management, the implementation function can be realized during the production process. At the time of production, the producer cooperates with the program director to create a program in accordance with the planning.

4. Controlling

Controlling is the act of comparing the plan with the actual one. According to Koontz, the meaning of controlling is the measurement and correction of appearances with the aim of ensuring that the goals and plans having been decided have been implemented.

Controlling will be carried out in several phases, i.e. the determination of standards, the measurement of work results and the correction if there is any differences between the standards and the actual ones. In the television program production process, the function of controlling can be realized in the post production process. In the process, editor teams will edit the program materials and therefore, the content will be more attractive. The team will insert images or videos, graphics, backsound and other aspects that can beautify the program materials to be displayed.

The broadcasting media definitely has to be able to carry out various functions. These include the function of medium for entertainment media, information media 
and service media. To carry out all these functions and to fulfill the interests of advertisers, audiences as well as owners and employees, it is a challenge for the management(Lawson-Borders, 2006).

The mistakesthat broadcasting station managers frequently make is to start activities and make decisions without setting goals at first. The goal is an end result, end point or everything that will be achieved. Each activity goal can also be called a goal or target(Bennett \& Strange, 2011).

The purpose of setting goals in the broadcasting media is that departments and individuals with the main objectives of the broadcasting media should coordinate each activities(Sudibyo \& Patria, 2013). When the broadcasting media's goals are established, the goals of various departments and the personals working in the related departments can be planned and developed(Carley, Malik, Landwehr, Pfeffer, \& Kowalchuck, 2016). The individual goals must contribute the achievement of departmental objectives, and in turn the departmental objectives must be in line with the objectives of other departments as well as the general objectives of the related media broadcasting(Aji et al., 2017).

Finally, all objectives must meet the attainable, measurable, deadline and monitorable criteria. Once goals are set, plans or strategies can be drawn up to achieve them.

\section{Organizational Communication}

Communication has several levels. One of them is organizational communication. Pace \& Faules (1994) stated the functional definition of organizational communication as a display and interpretation of messages between communication units as part of a particular organization.

According to Goldhaber \& Barnett (1988)the definition of organizational communication as follows: "Organizational communication is the process of creating and exchanging messages within a network of interdependent relationships to cope with environmental uncertainty. Or in other words, organizational communication is the process of creating and exchanging messages in a network of interdependent relationships with each other to overcome uncertain or ever-changing environments.

Gani (2004)defines organizational communication as the sending and receiving of various messages within the organizations both in formal and informal groups of organizations.

Based on three definitions of organizational communication at above, the researchers conclude that the definition of organizational communication is a process of exchanging messages that occur in a formal and informal organization.

Organizational communication aims to facilitate, implement, and smooth the course of the organizations. With the creation of good organizational communication will make it easier to achieve company goals. On the other hand, Pace \& Faules (1994) states that there are four organizational communication objectives, i.e.:

1. Expressing thoughts, viewpoints and opinions

2. Sharing information

3. Stating expressions and emotions

4. Making coordination

\section{Creativity and Innovation}

Creativity means the uses of imagination and intelligence to achieve something or solution when overcoming the existing problems(Chapain, Cooke, De Propris, MacNeill, \& Mateos-Garcia, 2010). Being creative is not an innate ability that you take from your birth but it is created and trained in a kind of stimulating brain(Pratt \& Gornostaeva, 2009). Game or picture making can stimulate brain to think creatively. By practicing creative thinking, the inspiration to carry out, make and create something is wide open, and therefore, it can result in something innovative(Manning \& Sydow, 2007).

Innovation is a process of developing new ideas or incorporating new ideas into practical activities and therefore, the conversion of new ideas occurs in the beneficial application. The application of new ideas takes place in innovation process and it also results in better ways or methods of working something will produce something innovative.

Anyone has potential creativity. If we want to develop creatifity, we should prepare our brain to open wide and accept impulses or stimuli from outside. As brain is definitely extraordinary, it is very disappointed if we do not use it as much as possible(Chapain et al., 2010). Every event, life experience and little things occur in our surrounding, it can develop our creativity. Moreover, it is available that there are products to increase and develop our creativity.

\section{RESEARCH METHODS}

The research used case studies qualitative research methods. The case study is a series of scientific activities carried out in intensive, detail and indepth way 
for a program, event and activity in the level of individuals, a group of people, institutions or organization to get in-depth knowledge on the events. The selected events hereafter called a case is the real life events that remain ongoing and should not have been conducted. The case study can be conducted on positive development way called the prospective case study(Yin, 2006). It is required to find trends and directions of a case. The other case study relates to action research conducted by other competent parties.

\section{Primary Data}

The primary data in the research would be conducted through interviewing the informants and making observation. There were totally 8 (eight) informants from the television stations. There were two research collection techniques in this research, i.e. in-depth interviews and observation. Firstly, the interview types is selected because the informants are considered important in this research. They not only gave information about anything in relation to the research and gave sugestions about other evidences.

Secondly, the researchers used the data collection method of non-participant observation. In this research the researchers observed the process of pre-production, production and post-production in the television stations.

\section{ANALYSIS AND DISCUSSION}

Based on the data results, the production team of Metro TV applies 4 (four) functions of broadcast management as explained by Terry (1992)that there are four functions of basic management, i.e. planning, organizing, actuating and controlling.

\section{a. Planning}

In the process of program design, Metro TV's team carries out several changes. It can increase the rating and attract audiences' attention to watch particularly the target audiences having been determined previously.

The target audiences have the range of 20-40 years old. During the existing program, however, the loyal audiences who watch the program range 40 years of age and older. Therefore, during the process of the program design for the next season, the internal team focuses on the changes of the shows. It will be lighter and relax but remain focusing on the topics having being discussed. It can attract young generation.

The producer executive of Metro Icare program wants to reformat the program. There are some changes and emphasis in the aspects of hosts, resource persons, contents, treatment, gimmick and coordination in the team.
It is expected that the change of the program format can attract audience particularly from young generation.

\section{HOST}

The internal team decides the replacement of host. At first there were two hosts of Metro Icare with the physician profession, i.e. dr. Nadia Octavia and dr. Dejandra Rasnaya. Right now there are four (4) hosts. Each episode will have different hosts and so, it does not make monotonous and the audience will not feel bored as well. The additional hosts of Metro Icare are drg. Stephanie Cecillia and dr. Farhan Mari Isa.

\section{RESOURCE PERSONS}

The selected resource persons in the TV program are those who have expertise in one field and considered to have the competency of conveying health information in the Metro Icare program. Metro Icare invites two resource persons. The first one is a primary care physician (PCP) and the other is a public figure or influencer known particularly among Millennial generation or public in general. The resource persons that Millenials know definitely can attract them to watch the program.

\section{CONTENT}

With the target audience of Millennials, the internal team of Metro TV particularly the producers and the creative team have to change the content. In this matter, the contents will be presented in simple way and so, the intended target audience will accept them.

\section{ARTISTIC ARRANGEMENTS}

In the previous season, the studio setting prefer indoor scenes, i.e. living room. However, the current studio setting has been change to outdoor scenes, i.e. garden.

\section{TREATMENT}

The treatment that the internal team has applied in the process of production has differences in each episode. It will not make the audience bored.

In each segment, the program of Metro Icare not only presents the discussion on diseases prevention or how to handle the diseases but also discusses an health issue comprehensively.

Instead providing the health information and education, Metro Icare also opens interaction forum with the hosts and resource persons. In the last segment, the hosts will ask questions from netizen and the invited physician will answer the questions. Furthermore, the Q\&A videos will be uploaded to the Instagram social media of Metro Icare.

\section{GIMMICK}

Gimmick applied in the program of Metro Icare aims at introducing the audience the discussion topics. If it is necessary, the team will invite those who can do the 
demonstration at the shooting location either inside the studio or outside the studio (on location). For example, in the episode of the millennial health diet, the producer and creative present sport gimmick at the gym room and morning run in the early segment. Moreover, the hosts will open the program and they will discuss millennial healthy life style.

\section{COORDINATION}

Coordination in the team has been carried out and it will avoid misunderstandings in the production process. The producer always coordinate all crews on duty both regular production in the studio or production outside the studio (on location). Producers always makes briefing before starting production, and therefore, all production crews on duty can understand the flow and the willingness of the producer to realize all concepts having been designed.

Before starting the production, the creative team assists the producer, conducting briefing at first to hosts and resource persons in relation to treatment in each segment including questions and gimmicks to be applied in the episode.

The planning function in the production process can be realized in the planning phase. It starts on Friday. On that day the internal team will conduct discussion on what themes and topics to be raised in the next episode. Before conducting a deeper discussion, the producer will make coordination with the sales team. The team will call clients on what products to be advertised in the next episode. After getting the agreement on the products, the producer with the support of the creative team will conduct research in advance on health topics that are recently being discussed and related to the products. On the same day, the production assistent will fill the editing booking form for the editing process in the next week. It has to be carried out because if it conduct the editing book at least one week before.

On Monday, the creative team has written a script on the basis of the treatment that the producer has approved. Moreover, the production assistent has prepared potential resource persons to be invited in the episode. Metro Icare presents 2 (two) resource persons, i.e. doctor and non-doctor. The non-doctor resource person to be invited in the program definitely has passed some consideration phases. The phases include appearance, age, profession and the factors that the resource person will represent the target audience having been decided before. Subsequently, the creative team sends the script draft to the clients for preview. The clients usually revise a number of questions that the hosts will ask to the resource persons. After getting an agreement between the internal team and clients, the production assistent immediately contact the potential resource persons who will be present on Wednesday for conducting the taping. On the same day, the production assistent will fill the studio booking form along with the equipment, the booking of ENG team if it is necessary for shooting outside the studio as well as the consumption memo.

On Tuesday, the creative team will send the revised script to clients. On the same day, the production assistent will prepare a memo for makeup and wardrobe of the hosts and resource persons. Moreover, the production assistent will prepare transportation for the hosts and resource persons by making an order via website http://metrotvfms.hibautama.com.

The producer will cross check all internal teams on all pre-production phases. It starts from the script, hosts and resource persons, location, property to administration. It relates to the statement of Morissan that in the planning it must decide what must be carried out, when, how and who will conduct them.

In the planning stage, a producer will get support from the creative team setting the concepts and finalizing the ideas to be aired in the episode. Moreover, the producer will decide the schedule of production both production that is conducted in the studio, outside the studio or coverage in field. In the planning phase, the producer will decide crews to be involved in the production process.

\section{b. Organizing}

The function of organizing can be established when the division of tasks is made during the production process. Behind the success of a television program, there is the role of the production staff who works hard. Like other television programs in general, the structure of organization in the Metro Icare program is under the leadership of producer executive with the tasks of designing the concepts and program format and guard and supervise the producer in the process of producing the television program.

As producing a television program, a producer executive gets assistance from a producer. Both will realize a program concept to be aired on television. The producer has important role. A producer will manage the production process from the pre-production phase, production pase to the post-production.

The producer of Metro Icare gets help from several production staff and they have each role and tasks, i.e. two production assistants and one creative man.

The creative man of Metro Icare has tasks of designing the script on the basis of the treatment that the 
producer has decided. A creative man has responsibility to the content presented in a television program. He/she definitely has great role in the pre-production phase. However, in the production phase a creative man still has tasks, i.e. conducting briefing together with the hosts and resource persons concerning the flow of the program as well as supervising and keeping the content in appropriate to what has been designed.

There are two production assistants in the program of Metro Icare. The two assistants have different tasks and responsibilities. In the division of tasks, one production assistant has the responsibility of non-technical matters, such as memos and administration and the other relates to technical matters, such as coverage to the field.

As with television programs in general, during the production process, the internal team gets support from some production crews such as cameraman with the tasks of taking pictures, lightingman with the tasks of managing lighting, audioman whose tasks are sound management, switcherman with the tasks in MCR to control the shows, property team with the tasks of preparing and arrangingall properties to be used in the sets, makeup and wardrobe whose tasks put on makeup and determining costumes to be worn by the hosts, the graphic teams whose tasks of making graphic touches to be displayed as well as the editor with the tasks of beautifying the show before broadcasted on television.

\section{c. Actuating}

In the broadcast media management, the function of actuating can be realized during the production process. The production phase of Metro Icare is divided into two types, i.e. regular taping and on loc taping. The regular taping is conducted in studio 3 Metro TV on Wednesday at 13:00 pm. Moreover, the on loc taping is usually conducted in the same day but in the different time depending on the demand.

\section{d. Controlling}

The function of controlling can be realized during the post production process. In the process, the editor team will edit the program materials and therefore, it can be presented with more attractive appearance after inserted images or videos, graphics, backsounds and other aspects that can beautify the program materials to be displayed.

Producers and production assistants still supervise the editors in the editing process, and so it still keep coordinating with the editors. It is intended that the goals and willingness of producers can be conveyed through the editing process that the editors have conducted.
After the show materials have passed the offline and online editing phase, it will be submitted to the quality control department that function is to determine that the material is suitable for broadcasting on television and does not violate the existing SOP.

After the materials are broadcasted on television, the team will receive an email from the production secretariate on the rating that the Research and Development Department will issue. After applying some changes, the calculated rating of Metro Icare has risen. Despite the increase is not so significant, it is stated that it still needs the improvement from before.

Based on the data obtained from the Research and Development Team, in the episode of "Gaya Hidup Jaman Now: Kerja Sambil Ngopi" (Today Lifestyle: Working While Having Coffee) aired on September 16, it got the rating 0.1 and in the episode of "Recharge Tubuh Saat Travelling" (Recharge the Body When Travelling) aired on September 23, 2018 it got the rating of 0.2. However, after applying the changes, the rating rose to 0.5 in the episode of "Pentingnya Nutrisi dalam Masa Pra Kehamilan" (The Importance of Nutrition During PrePregnancy) aired on December 9, 2018. Moreover, the share in the episode reached the number 4 but in the previous episode the share only reached the number of 1.0 and 1.6.

Each weekend, therefore, the internal team will evaluate the program of Metro Icare in each episode. The evaluation results aims to avoid mistakes and maximize the program of Metro Icare in the next episode.This is in line with the statement of Morissan (2011)that supervision is a process to find out how much the organizational goals have been achieved or not.

In this matter, the internal team of Metro Icare has carried out the function of supervision. It can be seen on the basis of evaluation the team has conducted after the production process along with the weekly rating results obtained from the RND team, the internal team of Metro Icare always monitors the rating development, and therefore, the team can know whether the results has reached the target having been made before or not.

The innovations that the internal team has applied have positive impact to the rating development. In the past in the episode of "Gaya Hidup Jaman Now: Kerja Sambil Ngopi" (Today Lifestyle: Working While Having Coffee) aired on September 16, it got the rating 0.1. However, after the team has applied the changes, the rating rose to 0.5 in the episode of "Pentingnya Nutrisi dalam Masa Pra Kehamilan" (The Importance of Nutrition During PrePregnancy) aired on December 9, 2018. Moreover, the share in the episode has reached the number 4.0 while in 
the previous episode the share only reached the number 1.0 .

However, the application of these aspects will not run smoothly if the internal team cannot apply the function of the organizational communication properly. This is in line with what Goldhaber has explained in his book Organizational Communication and he has given the following definition of organizational communication: "Organizational communication is the process of creating and exchanging messages within a network of interdependent relationships to cope with environmental uncertainty. Or in other words, the organizational communication is the process of creating and exchanging messages in a network of interdependent relationships with each other to overcome uncertain or ever-changing environments.

In this matter, the internal team of Metro Icare has applied the function of good organizational communication. It is shown in the internal communication process between producer executive, producer, production assistant, creative, sales team and production crews who carry out their tasks in the field(Briandana \& Mukti, 2019). They exchange messages within the production team. It frequently changes. It means that the team of Metro Icare always presentsthe shows with different concept and treatment in each episode.

Therefore, it can be concluded that increasing the rating of Metro Icare can be shown from amount of hosts, gimmick application, the change of setting, studios, and good communication within the team.

\section{CONCLUSION}

In this research it can be concluded that, a new strategy in broadcast management is needed to maintain business continuity particularly the application of 4 (four) functions in management, i.e. planning, organizing, actuating and controlling.

1. Planning

In the planning phase, Metro Icare's executive producer decided to reformat the Metro Icare programsand he providessome innovations to several aspects, i.e. the host, resource persons, content, artistic arrangement, treatment, gimmick, as well as good coordination within the team. The planning function in the production phase can be realized through the process of pre-production process in a kind of internal meetings, theme determination, treatment arrangement, the decision on who will become the resource persons, budgeting, script making.

2. Organizing
The organizing function can be realized during the division of tasks in the production process. Metro Icare's internal team consists of 5 people, i.e. executive producer, producer, creative, and two production assistants with each respective duties and responsibilities. However, in the production process the internal team usually gets assistence from field crews, such as program director, floor director, cameraman, lightingman, audioman, switcherman, makeup and wardrobe, property team, graphic team, and editor.

3. Actuating

The implementation function can be realized when the production process goes on. In the production phase of Metro Icare it divides into two types, i.e. the regular taping and the on loc taping. The regular taping takes place at Studio 3 Metro TV on Wednesday at 1:00 p.m. Moreover, the on loc taping is usually conducted on the same day but different time. It will be adjusted to the existing needs.

4. Controlling

After the materialsare broadcasted on television, the team will receive emails from the production secretariat regarding the rating issued by the research and development (RND) department. Considering the rating of Metro Icare and after applying several correction, the increase occurs. Despite it is not too significant but it can be stated it is better than before.

\section{REFERENCES}

[1] Aji, L. S., Wibisono, G., \& Gunawan, D. (2017). The adoption of TV white space technology as a rural telecommunication solution in Indonesia. In 2017 15th International Conference on Quality in Research (QiR): International Symposium on Electrical and Computer Engineering (pp. 479-484). IEEE.

[2] Baran, S. J., \& Davis, D. K. (2011). Mass Communication Theory: Foundations, Ferment, and Future. Cengage Learning.

[3] Bennett, J., \& Strange, N. (2011). Television as digital media. North Carolina: Duke University Press.

[4] Briandana, R., \& Mukti, D. A. (2019). Understanding Photography Representation: Humanism and Social Criticism in Social Media. In International Conference on Psychology and Communication 2018 (ICPC 2018). Atlantis Press.

[5] Carley, K. M., Malik, M., Landwehr, P. M., Pfeffer, J., \& Kowalchuck, M. (2016). Crowd sourcing disaster management: The complex nature of Twitter usage in Padang Indonesia. Safety Science, 90, 48-61.

[6] Chapain, C., Cooke, P., De Propris, L., MacNeill, S., \& Mateos-Garcia, J. (2010). Creative clusters and innovation. 
Putting Creativity on the Map. NESTA London.

[7] Danaher, P. J. (1995). What happens to television ratings during commercial breaks? Journal of Advertising Research, 35(1), 37.

[8] Eilein Landers, D., \& Chan-Olmsted, S. (2004). Assessing the changing network TV market: A resource-based analysis of broadcast television networks. Journal of Media Business Studies, 1(1), 1-26.

[9] Fiske, J. (2012). Pengantar ilmu komunikasi. Jakarta: Rajawali Press.

[10] Gani, D. S. (2004). Leadership in Indonesia: A Case for Managing. Leading in High Growth Asia: Managing Relationship for Teamwork and Change, 195.

[11] Goldhaber, G. M., \& Barnett, G. A. (1988). Handbook of organizational communication. Praeger Pub Text.

[12] Greer, C. F., \& Ferguson, D. A. (2011). Using Twitter for promotion and branding: A content analysis of local television Twitter sites. Journal of Broadcasting \& Electronic Media, 55(2), 198-214.

[13] Hisamatsu, R., Mitsuhashi, T., Saito, T., \& Sakao, K. (2008, December 16). Business management method, business management apparatus and data broadcast delivery method. Google Patents.

[14] Jung, E. H., \& Walden, J. (2015). Extending the Television Brand: An Examination of Why Consumers Use Broadcast Network Web Sites. Journal of Broadcasting \& Electronic Media, 59(1), 94-111.

[15] Küng-Shankleman, L. (2012). Inside the BBC and CNN: Managing media organisations. Routledge.

[16] Lawson-Borders, G. L. (2006). Media organizations and convergence: case studies of media convergence pioneers. Routledge.

[17] Linder, J. R., \& Gentile, D. A. (2009). Is the television rating system valid? Indirect, verbal, and physical aggression in programs viewed by fifth grade girls and associations with behavior. Journal of Applied Developmental Psychology, 30(3), 286-297.

[18] Malmelin, N., \& Moisander, J. (2014). Brands and branding in media management-Toward a research agenda. International Journal on Media Management, 16(1), 9-25.

[19] Manning, S., \& Sydow, J. (2007). Transforming creative potential in project networks: How TV movies are produced under network-based control. Critical Sociology, 33(1-2), 19-42.

[20] Mcguire, D., Stoner, L., \& Mylona, S. (2008). The role of line managers as human resource agents in fostering organizational change in public services. Journal of Change Management, 8(1), 73-84.

[21] Morissan. (2011). Manajemen Media Penyiaran: Strategi Mengelola Radio dan Televisi. Jakarta: Kencana.

[22] Oberg, J. K. (2000). Facing the digital future, darkly: Television station managers' approach towards the implementation of digital broadcasting. Unpublished Working Paper, Http://www. Beaweb. org/bea2000/papers/oberg. Pdf.

[23] Pace, R. W., \& Faules, D. F. (1994). Organizational communication . Eaglewood Cliffs. New Jersey: Prentice Hall Inc.

[24] Pratt, A. C., \& Gornostaeva, G. (2009). The governance of innovation in the film and television industry: A case study of London, UK. Creativity, Innovation and the Cultural Economy, 119-136.

[25] Sudibyo, A., \& Patria, N. (2013). The television industry in post-authoritarian Indonesia. Journal of Contemporary Asia, 43(2), 257-275.

[26] Terry, G. R. (1992). Personnel Management. United Kingdom: Macmillan Coll Div; Subsequent edition.

[27] Yin, R. K. (2006). Case study methods. Handbook of complementary methods in education research (Vol. 3). London: Routledge. 